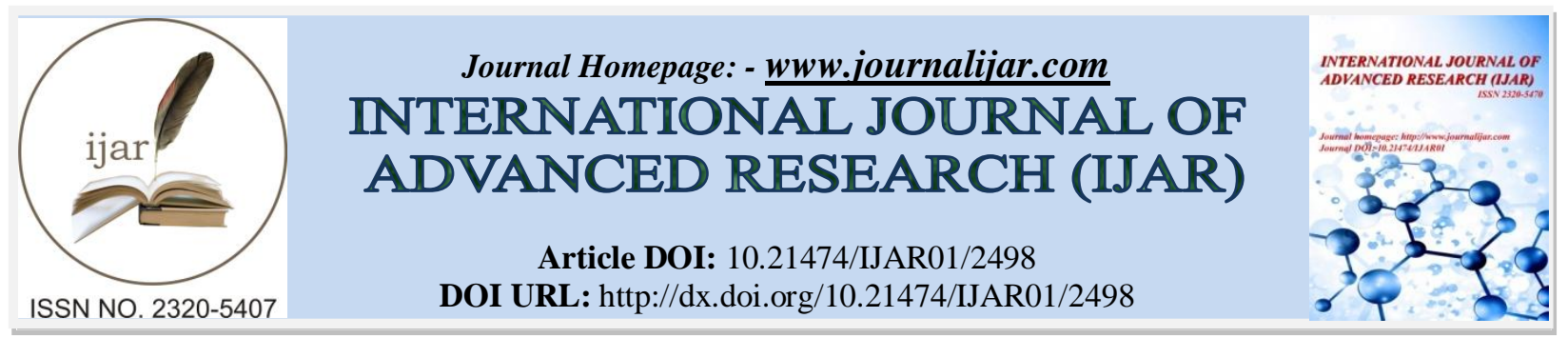

RESEARCH ARTICLE

\title{
CLINICOPATHOLOGICAL SIGNIFICANCE OF CANCER STEM CELLS (CD 44 AND CD133) AND INFLAMMATORY MICROENVIRONMENT (TAMS AND MAST CELLS) IN COLORECTAL CANCER: IMMUNOHISTOCHEMICAL STUDY.
}

\author{
Lubna O. Abdel-Salam ${ }^{1}$, Hala M. El-hanbuli ${ }^{2}$, Mostafa A. Abousarie ${ }^{2}$ and Rasha Haggag. \\ 1. Department of Pathology, Faculty of Medicine, Cairo University, Egypt. \\ 2. Department of Pathology, Faculty of Medicine, Fayoum University, Egypt. \\ 3. Department of Medical Oncology, Faculty of Medicine, Zagazig University, Egypt.
}

\section{Manuscript Info}

\section{Manuscript History}

Received: 25 October 2016

Final Accepted: 23 November 2016

Published: December 2016

Key words:-

Colorectal carcinoma, CDC133, CD44, CD68, CD117, cancer stem cells, inflammatory microenvironment.

\begin{abstract}
Background: Many studies have investigated the role of CSCs and the role of the inflammatory microenvironment in CRC especially their relation to prognosis.

Materials and Methods: To examine the prognostic significance of CSCs and the inflammatory microenvironment in CRC, we selected 2 cancer stem cell markers; CD44 and CD133 and 2 inflammatory microenvironment members; TAMs and mast cells. Sixty cases of radical resection specimens of CRC collected as fresh samples and paraffin blocks from archives used for CD133, CD44, CD68 and CD117 immunohistochemistry.

Results: There was a statistically significant relation for CD133 expression and the $(\mathrm{T})$ status of the tumor $(\mathrm{P}=0.012)$, while $\mathrm{CD} 44$ expression was significantly related to both tumor size $(\mathrm{P}=0.006)$ and Dukes classification $(\mathrm{P}=0.019)$. The positivity of both markers was significantly related to metastasis $(\mathrm{P}=0.023)$. The expression of $\mathrm{CD} 68$ was statistically significant in relation to the tumor size $(\mathrm{P}=0.018)$, the $\mathrm{T}(\mathrm{P}=0.007)$ and the $\mathrm{N}(\mathrm{P}=0.049)$ status of the tumor. The expression of $\mathrm{CD} 117$ was also significantly related to the $\mathrm{T}$ status of the tumor $(\mathrm{P}=0.011), \quad \mathrm{M}$ status $(\mathrm{P}=0.003)$ and to Dukes classification of the tumor $(\mathrm{P}=0.001)$. The $\mathrm{CRC}$ cases with infiltration of moderate and strong intensity for both markers had a strongly significant relation to the $\mathrm{T}$ status $(\mathrm{P}=0.027)$, the metastasis $(\mathrm{P}=0.034)$ and the presence of lymphovascular invasion $(\mathrm{P}=0.011)$. The expression of $\mathrm{CD} 133$ was significantly related to that of $\mathrm{CD} 44(\mathrm{P}=0.013)$ and to that of $\mathrm{CD} 117$ $(\mathrm{P}=0.013)$ but was not related to the expression of $\mathrm{CD} 68(\mathrm{P}=0.92)$. CD44 expression was significantly related to $\mathrm{CD} 68$ expression $(\mathrm{P}=0.013)$ but not related to the expression of $\mathrm{CD} 117(\mathrm{P}=0.137)$.

Conclusion: CSCs (CD133 and CD44) and inflammatory microenvironment (TAMs and mast cells) play a role in CRC progression referring to a possible cross-talk between them which needs further studies for confirmation.
\end{abstract}

Copy Right, IJAR, 2016,. All rights reserved. 


\section{Introduction:-}

Colorectal cancer (CRC) is one of the most common visceral malignancies (1). And it is the fourth most common cause of all cancer deaths (2).The tumorigenesis of CRC is one of the most studied tumor development in the world. But with no clear etiology, or pathogenesis as in other malignancies (3).

Despite the increased knowledge and better understanding of cancer, the exact origin still not oblivious (4) Tumorinitiating cells or cancer stem cells (CSCs) are present in small population of cells of many tumors; they are responsible for tumor progression, metastasis, and chemo-radiation treatment resistance.

This new CSC model has given a new outlook on the cancer origin and tumor populations constitution by the development of the heterogeneous hierarchy, shifting to a novel pattern that inspires new strategies to fight cancer (5).

Many CSCs of surface markers are expressed in CRC, including CD133 (6), ALDH1(7), the epithelial specific antigens CD326, CD44, and CD166 (8).

The trans-membrane glycoprotein molecule, CD133 which has a molecular weight of $120 \mathrm{kDa}$ on chromosome $4 \mathrm{p} 15.32$, is considered as a promising cell surface marker (9), Giving cancer cells the ability to self-renew, retain tumorigenicity, and post- treatment tumor regeneration (10).

CD44is a hyaluronic acid receptor cell adhesion molecule, which is involved in cell growth, differentiation and survival. CD44 plays a major role in cancer cell migration as it is associated with tumor initiation and colony formation, as well as lymph node infiltration, stage, and prognosis (11). CD44+ sorted CRC cells displayed high tumorigenicity, especially if combined with CD133+ cells, whereas CD44- cells could not form new tumors (12).

The host immune system is a microenvironmental factor that alters tumor development (13). A recent concern clears the link between cancer and inflammation (14). Survival can be positively influenced by tumors Inflammatory reactions (15) or alternatively can be associated with development of metastases and disease progression (16).

The most plentiful immune population in the tumor microenvironment are macrophages (17). The tumor associated macrophages (TAMs) role in colorectal cancer tumorogenesis is complex, because they can both promote and prevent tumor development (18). Mast cells are progeny of CD34+ hematopoietic stem cells involved in hypersensitivity reactions (19). Some studies proved that MC plays an important role in innate and adaptive immunity, intervening mainly in inflammatory processes and angiogenesis (20), closely inter linked processes, and also related to development and progression of the tumor (21).

The idea that CRC pathogenesis might be induced by transformed CSCs was approved by several studies. CSCs have the ability to self-renew and to unusually differentiate, associating also the interaction between the microenvironment and Co-CSCs (22- 23).

We aimed by this work to examine the possible significance of CSCs and the inflammatory microenvironment in CRC using immunohistochemistry. So we selected two putative cancer stem cell markers; CD44 and CD133 and two inflammatory microenvironment members; TAMs and mast cells to compare their immunohistochemical expression in primary CRC with and without metastases.

\section{Materials and Methods:-}

\section{Study Design:-}

A study, with 60 cases of radical resection specimens of CRC, collected as fresh samples and paraffin blocks from archives of Pathology Department, Faculty of Medicine, Cairo University and a private laboratory, during the time period between January 2015 and May 2016. Complete clinicopathological data of all cases were collected from the pathology reports, including age, sex, site, size, tumor type, vascular emboli, lymphatic invasion, and perineural invasion, and grade.

Radiological work up was done also to assess the stage including TNM (according to American Joint Committee, 2010) and Duke's staging systems. Cases lacking proper data were excluded. The evaluation of 
immunohistochemical staining results was carried out blindly by three different pathologists (the researchers). Institutional review board approval was obtained before the collection of data.

\section{Histopathology and Immunohistochemistry:-}

Formalin-fixed paraffin embedded sections from each tumor tissue block were cut at 3-5 micron thickness. One section was mounted on a glass slide then stained with routine Haematoxylin and Eosin stain (H\&E) for histopathological re-evaluation. The other four sections were mounted on positive charged slides then immunostained with anti CD133 antibody, anti CD 44 antibody, anti CD68 antibody(for detection of TAM's), and anti CD117 antibody (for detection of mast cells).

\section{3immunostaining:-}

For an immunohistochemical analysis of the CD 133 protein, $4 \mu \mathrm{m}$ sections were de-waxed and rehydrated, and antigen retrieval was performed by microwave heating for $15 \mathrm{~min}$ in a $10 \mathrm{mM}$ citrate buffer at $\mathrm{pH} 6.0$. Next, the sections were reacted with rabbit monoclonal antibody against the human CD133 proteins (1:100 dilution; clone C24B9, Cell Signaling Technology, Danvers, MA, USA). Later on, a standard rapid En Vision technique (REALTM EnVision $^{\mathrm{TM}}$ Detection System, Peroxidase/DAB+, Rabbit/Mouse, Code K5007, Dako, Denmark) Sections on adhesion microscope slides were deparaffinized using xylene then rehydrated with distilled water.To reduce nonspecific background staining due to endogenous peroxidase, the slides were incubated in hydrogen peroxide for 5 minutes then washed in buffer 2 time. For more blockage of nonspecific background staining the slides were incubated in super block for 10 minutes then washed in buffer 1 time. Then tissue sections were boiled in $10 \mathrm{mM}$ citrate buffer (Lab Vision Corporation. USA) for 20 minutes followed by cooling in room temperature for 20 minutes. Primary antibody was applied and incubated for 30 minutes at room temperature then washed in buffer 4 times. EconoTekbiotinylated Anti-polyvalent was applied and incubated for 30 minutes at room temperature then washed in buffer 4 times. EconoTek HRP was applied and incubated for 30 minutes at room temperature then rinse in buffer 4 times. DAB was prepared by adding 4 drops (200 ul) DAB chromogen to DAB substrate $(5 \mathrm{ml}$.) then applied to tissue sections and incubated for 10 minutes. Finally counter stained in hematoxylin for 3 minutes.

\section{44 immunostaining:-}

Paraffin section from each case was processed for immunostaining using CD44 Std. / HCAM AB-4 (0.7 ml. of antibody prediluted $0.05 \mathrm{~mol} / \mathrm{L}$ Tris- $\mathrm{HCl}, \mathrm{pH} 7.6$ containing stabilizing protein and $0.015 \mathrm{~mol} / \mathrm{L}$ sodium azide Thermo Fisher Scientific. UK) and EconoTek HRP Anti-Polyvalent (DAP) ready-to use (ScyTek Laboratories inc. USA) detection system. The steps of processing were performed as before.

\section{CD117 immunostaining:-}

Same initial steps were performed. The sections then were reacted with rabbit polyclonal antibody for CD117 diluted at 1: 100 for $60 \mathrm{~min}$ at room temperature, and then were subsequently stained by the universal immunoperoxidase polymer method, according to the protocol provided by the manufacturer. Positive reactions were visualized with diaminobenzidine, followed by counterstaining with haematoxylin. Mast cells were delineated by CD117 immunostaining.

\section{68 immunostaining:-}

The same steps for processing were undergone. Reagent provided was Ready-to-use monoclonal mouse antibody provided in liquid form in a buffer containing stabilizing protein and $0.015 \mathrm{~mol} / \mathrm{L}$ sodium azide, Clone: KP1, Isotype: $\operatorname{IgG1}$, kappa. Immunogen was lysosomal fraction of human lung macrophages.

For each marker used a positive control was used and the primary antibodies were omitted in the case of negative controls.

\section{Interpretation of Immunohistochemistry:- CD 133immunostaining interpretation:-}

The whole sections were screened for CD133 expression and cases were segregated as, CD133 negative if absent expression or less than $10 \%$ of tumor surface area, and CD133 positive (cytoplasmic and/or membranous immunoreactivity) if CD133 staining was detected in more than $10 \%$ of the entire tumor area (24). 


\section{44 immunostaining interpretation:-}

CD44 stained sections were examined at high power for immunohistochemical expression and were divided into negative (no immunoreactivity in any cells) and positive (cytoplasmic and/or membranous immunoreactivity present) (25).

\section{CD68 immunostaining interpretation:-}

The immunohistochemical CD68 was used to detect TAMs in peritumoralstroma then three areas with high density of macrophages were selected with low power within or around tumor nests. Counting of macrophages was performed by using a magnification of x 200 field (x 20 objective and x 10 ocular pieces)(26). They were classified as $0=$ negative, positive ones into $1=$ infiltration with mild intensity $(<5 / 10 \mathrm{HPF}), 2=$ infiltration with moderate intensity (5-10/10 HPF), and 3 =infiltration with marked intensity (>10/ $10 \mathrm{HPF})$.

\section{CD117 immunostaining interpretation:-}

The scoring systems available, as that applied by (27), unfortunately classified the results into $0=$ no mast cells/ $1=$ positive for mast cells. For more accuracy, we made a modification where we regarded the positive ones into $1=$ infiltration with mild intensity $(<5 / 10 \mathrm{HPF}), \quad 2=$ infiltration with moderate intensity $(5-10 / 10 \mathrm{HPF})$, and 3 $=$ infiltration with marked intensity $(>10 / 10 \mathrm{HPF})$.

We evaluated the relationship between the markers expression and the available clinicopathological features of the patients and also the relationship between the markers themselves.

\section{Statistical Analysis:-}

Computer software package Statistical Package for Social Sciences (SPSS) vs. 21 was used in the analysis. The significance of the results were assessed by determining the probability factor " $\mathrm{P}$ " value. A $\mathrm{P}$ value of less than 0.05 was considered statistically significant. The numerical data were statistically presented in terms of range, mean, standard deviation and median. Categorical data were summarized as percentages. Comparison between more than two groups of means was done using a non parametric test equivalent to analysis of variances (Anova test). The relation between variables was done using the pearson chi-square test, independent T test, Two way Anova, Yates' correction of Chi-square test and Fisher's exact test for small sample size.

\section{Results:-}

The baseline characteristics of the 60 patients of this retrospective study showed that, ages ranged from 25 to 78 years with mean age $(53.78 \pm 11.06)$ years, there was female preponderance ( 24 male and 36 female patients) with a male to female ratio of 2:3. The lesions were colonic in 43 cases (71.7\%) and rectal in 17 cases $(28.3 \%)$. As regard the histological type of colonic cancer, 42 cases $(70 \%)$ were classified as invasive adenocarcinoma, 16 cases (26.7\%) were classified as invasive mucinous carcinoma and 2 cases $(3.3 \%)$ as undifferentiated carcinoma. The histological grade was II in $52(86.7 \%)$ of cases and III in $8(13.3 \%)$ cases. As regards the tumor stage (T stage), 8 $(13.3 \%)$ cases presented with T2, $40(66.7 \%)$ cases presented with T3, $6(10 \%)$ cases presented with T4a and 6 (10\%) casespresented with T4b. The tumor size ranged from 3 to $17 \mathrm{~cm}$ with a median of $6.75 \mathrm{~cm}$. Lymph nodes in $26(43.3 \%)$ cases had no metastatic deposits N0 while in $34(56.7 \%)$ of cases had lymph node metastasis. 10 (16.7\%) cases presented with N1a, 14 (23.3\%) presented with N2a while $10(16.7 \%)$ cases presented with N2b. 42 cases (70\%) showed no distant metastasis and 18 cases (30\%) presented distant metastasis. 6 cases (10\%) presented with M1a and 12 cases (20\%) presented with M1b. As regards Duke's stage, 6 cases (10\%) presented with Duke's B1, 18 cases (30\%) as B2, 16 cases $(26.7 \%)$ as $\mathrm{C} 2$ and 20 cases (33.3\%) as D.

\section{Stem cell markers:-}

The expression of CD133 was negative in $37(61.7 \%)$ cases (Figure 1) and positive in 23 (38.3\%) cases (Figure 1), while the expression of CD44 was negative in $33(55 \%)$ and positive in 27 (45\%) cases (Figure 2). The expression of both CD133 and CD44 was positive in only 15 cases and both were negative in 25 cases.

The relation of the immunohistochemical expression of both CSC markers to different clinicopathological features of the cases was summarized in table (1).

The only statistically significant relation for CD133 expression and the different clinicopathological features used was for the $(\mathrm{T})$ status of the tumor $(\mathrm{P}=0.012)$, while $\mathrm{CD} 44$ expression was significantly related to only both tumor 
size $(\mathrm{P}=0.006)$ and Dukes classification $(\mathrm{P}=0.019)$. The positivity of both markers was only significantly related to metastasis $(\mathrm{M})(\mathrm{P}=0.023$; Table 1).

Table 1:- Relation between CD133 and CD44 expressions in CRC and the clinicopathological factors.

\begin{tabular}{|c|c|c|c|c|c|c|c|c|c|}
\hline \multirow[t]{2}{*}{ Variable } & \multicolumn{2}{|c|}{ CD133 expression } & \multirow{2}{*}{$\begin{array}{c}\text { P- } \\
\text { value }\end{array}$} & \multicolumn{2}{|c|}{ CD44 expression } & \multirow{2}{*}{$\begin{array}{c}P \text { P- } \\
\text { value }\end{array}$} & \multicolumn{2}{|c|}{ CD133/44 } & \multirow{2}{*}{$\begin{array}{c}\text { P- } \\
\text { value }\end{array}$} \\
\hline & $\begin{array}{c}-v e \\
N=37\end{array}$ & $\begin{array}{c}+\mathrm{ve} \\
\mathrm{N}=23\end{array}$ & & $\begin{array}{c}-\mathrm{ve} \\
\mathrm{N}=33\end{array}$ & $\begin{array}{c}+\mathrm{ve} \\
\mathrm{N}=27\end{array}$ & & $\begin{array}{c}\text {-ve for } \\
\text { one or } \\
\text { both } \\
\mathrm{N}=45\end{array}$ & $\begin{array}{c}+ \text { ve for } \\
\text { both } \\
N=15\end{array}$ & \\
\hline $\begin{array}{l}\text { Age }(\mathbf{y r}) \\
\leq 60 \\
>60\end{array}$ & $\begin{array}{l}31 \\
6 \\
\end{array}$ & $\begin{array}{l}21 \\
2 \\
\end{array}$ & 0.405 & $\begin{array}{l}29 \\
4 \\
\end{array}$ & $\begin{array}{l}23 \\
4 \\
\end{array}$ & 0.76 & $\begin{array}{l}39 \\
6 \\
\end{array}$ & $\begin{array}{l}13 \\
2 \\
\end{array}$ & 1 \\
\hline $\begin{array}{l}\text { Tumor site } \\
\text { Colon } \\
\text { Rectum }\end{array}$ & $\begin{array}{l}27 \\
10\end{array}$ & $\begin{array}{l}16 \\
7\end{array}$ & 0.776 & $\begin{array}{l}23 \\
10\end{array}$ & $\begin{array}{l}20 \\
7\end{array}$ & 0.708 & $\begin{array}{l}35 \\
10\end{array}$ & $\begin{array}{l}8 \\
7\end{array}$ & 0.069 \\
\hline $\begin{array}{l}\text { Tumor size } \\
(\mathbf{c m}) \\
\leq 5 \\
>5\end{array}$ & $\begin{array}{l}9 \\
28\end{array}$ & $\begin{array}{l}9 \\
14\end{array}$ & 0.224 & $\begin{array}{l}5 \\
28\end{array}$ & $\begin{array}{l}13 \\
14\end{array}$ & 0.006 & $\begin{array}{l}11 \\
34\end{array}$ & $\begin{array}{l}7 \\
8\end{array}$ & 0.104 \\
\hline $\begin{array}{l}\text { T } \\
2 \\
3 \\
4 \mathrm{a} \\
4 \mathrm{~b}\end{array}$ & $\begin{array}{l}6 \\
27 \\
0 \\
4\end{array}$ & $\begin{array}{l}2 \\
13 \\
6 \\
2\end{array}$ & 0.012 & $\begin{array}{l}2 \\
25 \\
4 \\
2\end{array}$ & $\begin{array}{l}6 \\
15 \\
2 \\
4\end{array}$ & 0.152 & $\begin{array}{l}6 \\
31 \\
4 \\
4\end{array}$ & $\begin{array}{l}2 \\
9 \\
2 \\
2\end{array}$ & 0.902 \\
\hline $\begin{array}{l}\mathbf{N} \\
0 \\
1 \mathrm{a} \\
1 \mathrm{~b} \\
2 \mathrm{a} \\
2 \mathrm{~b}\end{array}$ & $\begin{array}{l}15 \\
6 \\
0 \\
8 \\
8 \\
\end{array}$ & $\begin{array}{l}11 \\
4 \\
0 \\
6 \\
2 \\
\end{array}$ & 0.631 & $\begin{array}{l}11 \\
4 \\
0 \\
10 \\
8\end{array}$ & $\begin{array}{l}15 \\
6 \\
0 \\
4 \\
2 \\
\end{array}$ & 0.084 & $\begin{array}{l}19 \\
8 \\
0 \\
10 \\
8\end{array}$ & $\begin{array}{l}7 \\
2 \\
0 \\
4 \\
2\end{array}$ & 0.938 \\
\hline $\begin{array}{l}\mathbf{M} \\
0 \\
1 \mathrm{a} \\
1 \mathrm{~b}\end{array}$ & $\begin{array}{l}27 \\
2 \\
8\end{array}$ & $\begin{array}{l}15 \\
4 \\
4\end{array}$ & 0.319 & $\begin{array}{l}25 \\
2 \\
6\end{array}$ & $\begin{array}{l}17 \\
4 \\
6\end{array}$ & 0.448 & $\begin{array}{l}35 \\
2 \\
8\end{array}$ & $\begin{array}{l}7 \\
4 \\
4\end{array}$ & 0.023 \\
\hline $\begin{array}{l}\text { Dukes } \\
\text { B1 } \\
\text { B2 } \\
\text { C1 } \\
\text { C2 } \\
\text { D } \\
\end{array}$ & $\begin{array}{l}6 \\
9 \\
0 \\
10 \\
12 \\
\end{array}$ & $\begin{array}{l}0 \\
9 \\
0 \\
6 \\
8\end{array}$ & 0.187 & $\begin{array}{l}2 \\
9 \\
0 \\
14 \\
8\end{array}$ & $\begin{array}{l}4 \\
9 \\
0 \\
2 \\
12 \\
\end{array}$ & 0.019 & $\begin{array}{l}6 \\
13 \\
0 \\
14 \\
12 \\
\end{array}$ & $\begin{array}{l}0 \\
4 \\
0 \\
3 \\
8 \\
\end{array}$ & 0.179 \\
\hline $\begin{array}{l}\text { Histo- grade } \\
2 \\
3\end{array}$ & $\begin{array}{l}31 \\
6 \\
\end{array}$ & $\begin{array}{l}21 \\
4\end{array}$ & 0.405 & $\begin{array}{l}27 \\
6 \\
\end{array}$ & $\begin{array}{l}25 \\
2\end{array}$ & 0.222 & $\begin{array}{l}39 \\
6\end{array}$ & $\begin{array}{l}13 \\
2\end{array}$ & 1 \\
\hline $\begin{array}{l}\text { PNI } \\
\text { Absent } \\
\text { Present }\end{array}$ & $\begin{array}{l}33 \\
4 \\
\end{array}$ & $\begin{array}{l}21 \\
2 \\
\end{array}$ & 0.791 & $\begin{array}{l}29 \\
4 \\
\end{array}$ & $\begin{array}{l}25 \\
2 \\
\end{array}$ & 0.545 & $\begin{array}{l}39 \\
6 \\
\end{array}$ & $\begin{array}{l}15 \\
0 \\
\end{array}$ & 0.136 \\
\hline $\begin{array}{l}\text { LVI } \\
\text { Absent } \\
\text { Present }\end{array}$ & $\begin{array}{l}33 \\
4\end{array}$ & $\begin{array}{l}21 \\
2\end{array}$ & 0.791 & $\begin{array}{l}29 \\
4\end{array}$ & $\begin{array}{l}25 \\
2\end{array}$ & 0.545 & $\begin{array}{l}41 \\
4\end{array}$ & $\begin{array}{l}13 \\
2\end{array}$ & 0.619 \\
\hline
\end{tabular}

TNM: according to AJCC 2010

Histo-grade: Histologic grade

PNI: preineural invasion

LVI: lymphovascular invasion 
Table 2:- Relation between CD68 and CD117 expressions in CRC and the clinicopathological factors:

\begin{tabular}{|c|c|c|c|c|c|c|c|c|c|}
\hline \multirow[t]{2}{*}{ Variable } & \multicolumn{2}{|c|}{ CD68 expression } & \multirow[t]{2}{*}{ P-value } & \multicolumn{2}{|c|}{ CD117 expression } & \multirow[t]{2}{*}{ P-value } & \multicolumn{2}{|c|}{ CD68/CD117 } & \multirow[b]{2}{*}{$\begin{array}{c}\text { P- } \\
\text { value }\end{array}$} \\
\hline & $\begin{array}{c}0 \text { or } 1+ \\
N=37\end{array}$ & $\begin{array}{c}2+\text { or } 3+ \\
N=23\end{array}$ & & $\begin{array}{c}0 \text { or } 1+ \\
\mathrm{N}=33\end{array}$ & $\begin{array}{c}2+\text { or } 3+ \\
N=27\end{array}$ & & $\begin{array}{l}0 \text { or } 1+ \\
\text { for one } \\
\text { or both } \\
N=51\end{array}$ & $\begin{array}{c}2+, 3+ \\
\text { for both } \\
\mathrm{N}=9\end{array}$ & \\
\hline $\begin{array}{l}\text { Age (yr) } \\
\leq 60 \\
>60\end{array}$ & $\begin{array}{c}31 \\
6 \\
\end{array}$ & $\begin{array}{c}21 \\
2 \\
\end{array}$ & 0.405 & $\begin{array}{c}31 \\
2 \\
\end{array}$ & $\begin{array}{c}21 \\
6 \\
\end{array}$ & 0.067 & $\begin{array}{c}44 \\
7 \\
\end{array}$ & $\begin{array}{l}8 \\
1 \\
\end{array}$ & 0.832 \\
\hline $\begin{array}{l}\text { Tumor Site } \\
\text { Colon } \\
\text { Rectum }\end{array}$ & $\begin{array}{l}27 \\
10\end{array}$ & $\begin{array}{c}16 \\
7\end{array}$ & 0.776 & $\begin{array}{l}21 \\
12\end{array}$ & $\begin{array}{c}22 \\
5\end{array}$ & 0.127 & $\begin{array}{l}38 \\
13\end{array}$ & $\begin{array}{l}5 \\
4\end{array}$ & 0.245 \\
\hline $\begin{array}{l}\operatorname{Size}(\mathrm{cm}) \\
\leq 5 \\
>5\end{array}$ & $\begin{array}{c}7 \\
30\end{array}$ & $\begin{array}{l}11 \\
12\end{array}$ & 0.018 & $\begin{array}{l}13 \\
20\end{array}$ & $\begin{array}{c}5 \\
22\end{array}$ & 0.079 & $\begin{array}{l}15 \\
36\end{array}$ & $\begin{array}{l}3 \\
6\end{array}$ & 0.813 \\
\hline $\begin{array}{l}\text { T } \\
2 \\
3 \\
4 \mathrm{a} \\
4 \mathrm{~b}\end{array}$ & $\begin{array}{c}4 \\
29 \\
4 \\
0\end{array}$ & $\begin{array}{c}4 \\
11 \\
2 \\
6\end{array}$ & 0.007 & $\begin{array}{c}4 \\
27 \\
0 \\
2\end{array}$ & $\begin{array}{c}4 \\
13 \\
6 \\
4\end{array}$ & 0.011 & $\begin{array}{c}37 \\
4 \\
3\end{array}$ & $\begin{array}{l}1 \\
3 \\
2 \\
3\end{array}$ & 0.027 \\
\hline $\begin{array}{l}\mathbf{N} \\
0 \\
1 \mathrm{a} \\
1 \mathrm{~b} \\
2 \mathrm{a} \\
2 \mathrm{~b}\end{array}$ & $\begin{array}{c}13 \\
6 \\
0 \\
8 \\
10 \\
\end{array}$ & $\begin{array}{c}13 \\
4 \\
0 \\
6 \\
0\end{array}$ & 0.049 & $\begin{array}{l}15 \\
6 \\
0 \\
4 \\
8\end{array}$ & $\begin{array}{c}11 \\
4 \\
0 \\
10 \\
2 \\
\end{array}$ & 0.084 & $\begin{array}{c}23 \\
9 \\
0 \\
10 \\
9\end{array}$ & $\begin{array}{l}3 \\
1 \\
0 \\
4 \\
1\end{array}$ & 0.447 \\
\hline $\begin{array}{l}\mathbf{M} \\
0 \\
1 \mathrm{a} \\
1 \mathrm{~b} \\
\end{array}$ & $\begin{array}{c}23 \\
6 \\
8 \\
\end{array}$ & $\begin{array}{c}19 \\
0 \\
4 \\
\end{array}$ & 0.095 & $\begin{array}{c}29 \\
2 \\
2 \\
\end{array}$ & $\begin{array}{c}13 \\
4 \\
10\end{array}$ & 0.003 & $\begin{array}{c}39 \\
4 \\
8\end{array}$ & $\begin{array}{l}3 \\
2 \\
4\end{array}$ & 0.034 \\
\hline $\begin{array}{l}\text { Dukes } \\
\text { B1 } \\
\text { B2 } \\
\text { C1 } \\
\text { C2 } \\
\text { D } \\
\end{array}$ & $\begin{array}{c}2 \\
9 \\
0 \\
10 \\
16 \\
\end{array}$ & $\begin{array}{l}4 \\
9 \\
0 \\
6 \\
4\end{array}$ & 0.115 & $\begin{array}{c}4 \\
11 \\
0 \\
14 \\
4\end{array}$ & $\begin{array}{c}2 \\
7 \\
0 \\
2 \\
16 \\
\end{array}$ & 0.001 & $\begin{array}{c}6 \\
16 \\
0 \\
15 \\
14\end{array}$ & $\begin{array}{l}0 \\
1 \\
0 \\
2 \\
6\end{array}$ & 0.120 \\
\hline $\begin{array}{l}\begin{array}{l}\text { Histological } \\
\text { grade }\end{array} \\
2 \\
3 \\
\end{array}$ & $\begin{array}{c}33 \\
4 \\
\end{array}$ & $\begin{array}{c}19 \\
4 \\
\end{array}$ & 0.466 & $\begin{array}{c}29 \\
4\end{array}$ & $\begin{array}{c}23 \\
4\end{array}$ & 0.760 & $\begin{array}{c}46 \\
5\end{array}$ & $\begin{array}{l}6 \\
3\end{array}$ & 0.056 \\
\hline $\begin{array}{l}\text { PNI } \\
\text { Absent } \\
\text { Present }\end{array}$ & $\begin{array}{c}35 \\
2\end{array}$ & $\begin{array}{c}19 \\
4\end{array}$ & 0.132 & $\begin{array}{c}29 \\
4\end{array}$ & $\begin{array}{c}25 \\
2\end{array}$ & 0.545 & $\begin{array}{c}45 \\
6\end{array}$ & $\begin{array}{l}9 \\
0\end{array}$ & 0.278 \\
\hline $\begin{array}{l}\text { LVI } \\
\text { Absent } \\
\text { Present }\end{array}$ & $\begin{array}{c}37 \\
0\end{array}$ & $\begin{array}{c}17 \\
6\end{array}$ & 0.001 & $\begin{array}{c}31 \\
2\end{array}$ & $\begin{array}{c}23 \\
4\end{array}$ & 0.261 & $\begin{array}{c}48 \\
3\end{array}$ & $\begin{array}{l}6 \\
3\end{array}$ & 0.011 \\
\hline
\end{tabular}

TNM: according to AJCC 2010

Histo-grade: Histologic grade

PNI: preineural invasion

LVI: lymphovascular invasion 
Table 3:- Relation between the expressions of different used immunohistochemical markers

\begin{tabular}{|c|c|c|c|c|c|c|}
\hline \multirow[t]{2}{*}{ Other markers } & \multicolumn{2}{|c|}{ CD133 expression } & \multirow[t]{2}{*}{ P-value } & \multicolumn{2}{|c|}{ CD44 expression } & \multirow[t]{2}{*}{ P-value } \\
\hline & $\begin{array}{c}-\mathrm{ve} \\
\mathrm{N}=37\end{array}$ & $\begin{array}{c}+\mathrm{ve} \\
\mathrm{N}=23\end{array}$ & & $\begin{array}{c}-\mathrm{ve} \\
\mathrm{N}=33\end{array}$ & $\begin{array}{c}+\mathrm{ve} \\
\mathrm{N}=27\end{array}$ & \\
\hline $\begin{array}{l}\text { CD44 } \\
\text {-ve } \\
+\mathrm{ve} \\
\end{array}$ & $\begin{array}{l}25 \\
12 \\
\end{array}$ & $\begin{array}{l}8 \\
15 \\
\end{array}$ & 0.013 & & & \\
\hline $\begin{array}{l}\text { CD68 } \\
0 \text { or } 1+ \\
2+\text { or } 3+\end{array}$ & $\begin{array}{l}23 \\
14\end{array}$ & $\begin{array}{l}14 \\
9\end{array}$ & 0.92 & $\begin{array}{l}25 \\
8 \\
\end{array}$ & $\begin{array}{l}12 \\
15\end{array}$ & 0.013 \\
\hline $\begin{array}{l}\text { CD117 } \\
0 \text { or } 1+ \\
2+\text { or } 3+\end{array}$ & $\begin{array}{l}25 \\
12 \\
\end{array}$ & $\begin{array}{l}8 \\
15 \\
\end{array}$ & 0.013 & $\begin{array}{l}21 \\
12 \\
\end{array}$ & $\begin{array}{l}12 \\
21 \\
\end{array}$ & 0.137 \\
\hline
\end{tabular}

$\mathrm{P}$ value of less than 0.05 was considered statistically significant
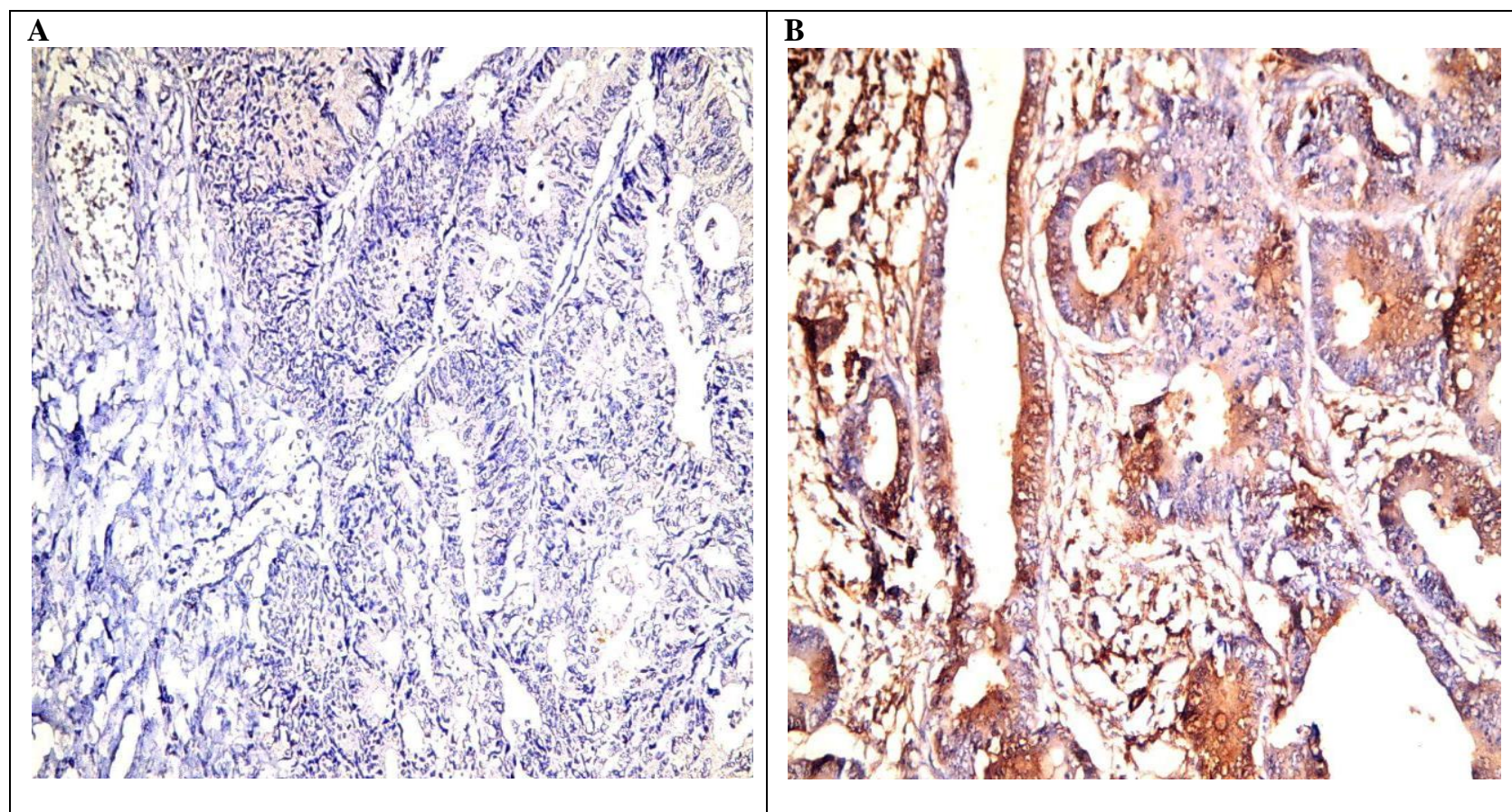

Figure1. Immunohistochemical staining of CD133 (A) negative staining (X100). (B) patchy staining of glandular epithelium (X100). 


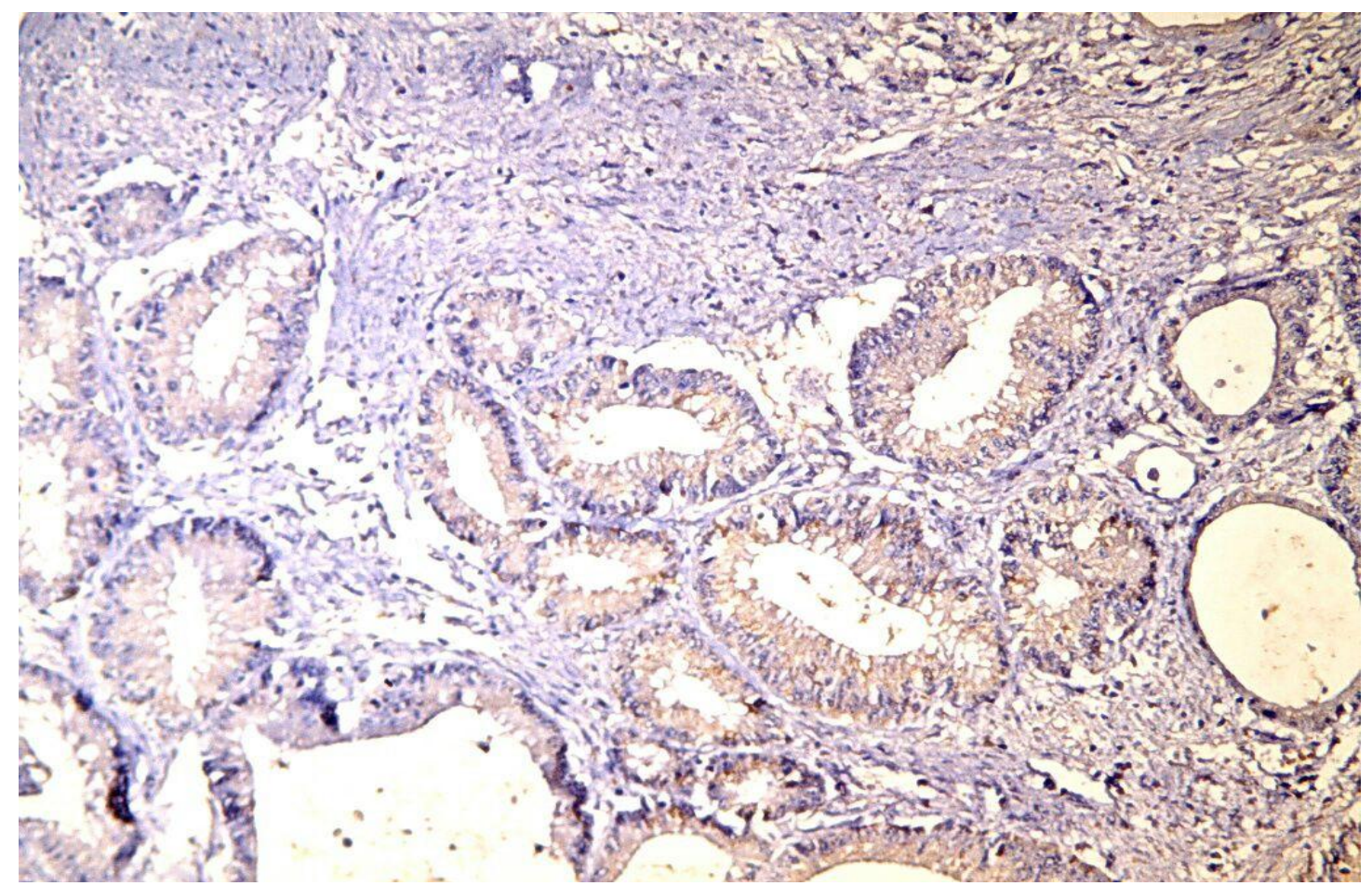

Figure 2:- Immunohistochemical staining of CD44 showing cytoplasmic staining of glandular epithelial linning (X100)

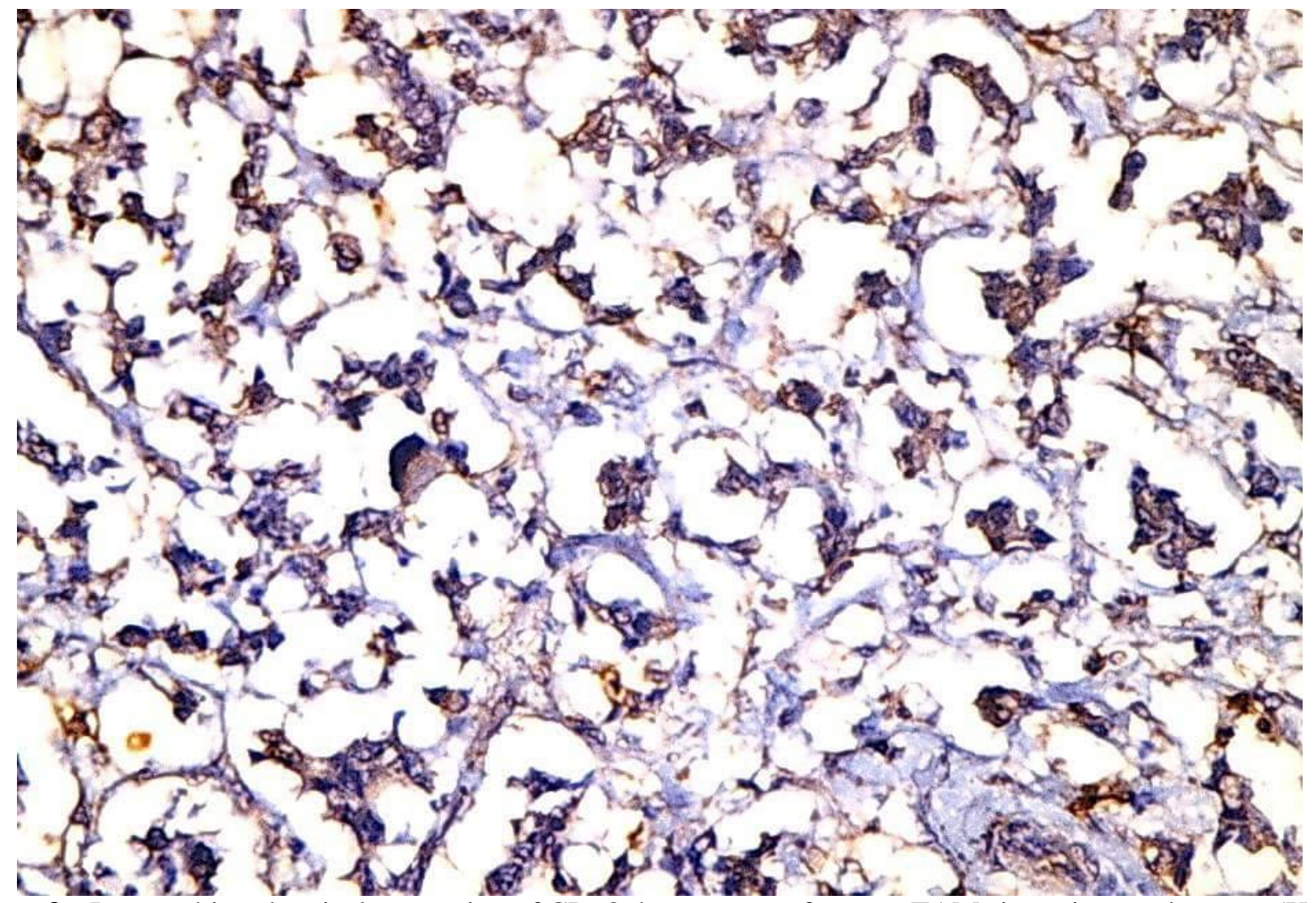

Figure 3:- Immunohistochemical expression of CD68 demonstrates frequent TAMs in peritumoral stroma (X400) 


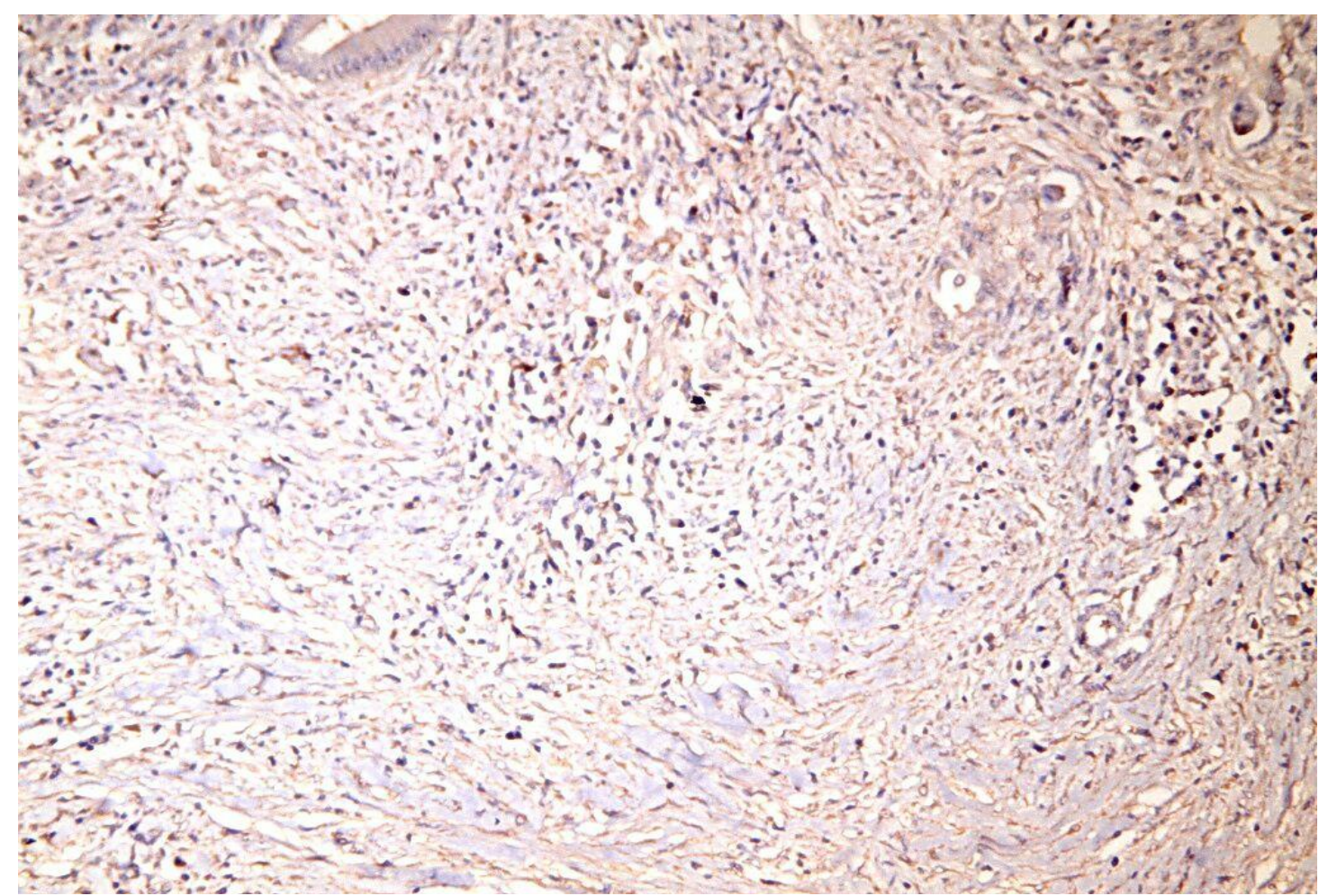

Figure 4:- Immunohistochemical expression of CD117 demonstrates prominent mast cell condensation in peritumoral stroma (X100)

\section{Inflammatory markers:-}

As regards CD68 expression, 16 (26.7\%) cases were negative for CD68 while 44 (73.3\%) cases were positive; 22 cases $(36.7 \%)$ showed infiltration with mild intensity, 6 cases $(10 \%)$ showed infiltration with moderate intensity while 16 cases (26.7\%) showed infiltration with strong intensity (Figure 3). While in CD117 expression, 12 cases (20\%) were negative and 48 cases (80\%) were positive; 21 cases (35\%) showed infiltration with mild intensity, 17 cases $(28.3 \%)$ showed infiltration with moderate intensity and 10 cases $(16.7 \%)$ showed infiltration with strong intensity (Figure 4), and for statistical purposes in both markers we grouped the negatively stained cases with the cases of infiltration with mild intensity(37 cases for CD68 and 33 for CD117) and the cases with infiltration with moderate intensity with that with strong intensity (23 cases for CD68 and 27 for CD117). 9 cases only showed infiltration with moderate to marked intensity for both CD68 and CD117 and only 4 cases that were negative for both.

The relation of the immunohistochemical expression of both inflammatory markers to different clinic pathological features of the cases was summarized in (Table 2).

The expression of CD68 was statistically significant only in relation to the tumor size $(\mathrm{P}=0.018)$, the $\mathrm{T}(\mathrm{P}=0.007)$ and the $\mathrm{N}(\mathrm{P}=0.049)$ status of the tumor. The expression of $\mathrm{CD} 117$ was also significantly related to the $\mathrm{T}$ status of the tumor $(\mathrm{P}=0.011)$ and it was also significantly related to $\mathrm{M}$ status $(\mathrm{P}=0.003)$ and Dukes classification of the tumor $(\mathrm{P}=0.001)$. The $\mathrm{CRC}$ cases with infiltration of moderate and strong intensity for both markers had a strongly significant relation to only the $\mathrm{T}$ status $(\mathrm{P}=0.027)$, the metastasis $(\mathrm{M})(\mathrm{P}=0.034)$ and the presence of lymphovascular invasion $(\mathrm{P}=0.011$; Table 2$)$.

Finally, regarding the relation between all used immunohistochemical markers, the expression of CD133 was significantly related to that of $\mathrm{CD} 44(\mathrm{P}=0.013)$ and to that of $\mathrm{CD} 117(\mathrm{P}=0.013)$ but was not related to the expression of $\mathrm{CD} 68$ ( $\mathrm{P}=0.92)$. CD44 expression was significantly related to $\mathrm{CD} 68$ expression $(\mathrm{P}=0.013)$ but not related to the expression of $\mathrm{CD} 117$ ( $\mathrm{P}=0.137$; Table 3 ). 


\section{Discussion:-}

Colorectal cancer prevalence is still on the rise in the developing countries due to the ageing population associated with a low in fruit and vegetables and high red meat, fat and processed food diet, despite of intense studies involving $\mathrm{CRC}$, still there is treatment resistance, poor disease relapse and survival (28).

It is widely accepted that Cancer stem cells (CSCs) constitute a biologically unique subset of stem like cells within the tumor cell population bulk and contribute in CRC cancer stem cells tumor development (23).

CD133 and CD44 are main markers that have been associated with Co-CSCs. An important matter explains which of these markers has the important influence on patient prognosis (28).

CD133+ CRC cells are more tumorigenic than CD133 negative ones (29). In our study CD 133 expression was negative in $37(61.7 \%)$ cases and positive in $23(38.3 \%)$ cases, the percentage is near that of revised previous studies $(30,31)$. A number of studies have demonstrated that CD133expression in CRC was correlated with recurrence, metastasis, chemotherapy resistance and survival (32). However the immunohistochemical analysis of CD133expression and its relevance to clinical and pathological features of CRC depends on sample type and size (33).In our work the only statistically significant relation for CD133 expression and the different clinicopathological features used was for the $(\mathrm{T})$ status of the tumor $(\mathrm{P}=0.012)$ which represents mostly the depth of invasion of the

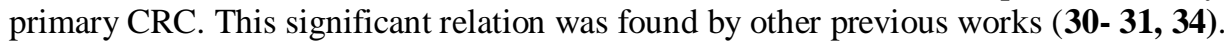

Because CSCs in CRC cannot be identified by CD133 expression alone (34) we determined also in our study the expression of CD44.The expression of CD44 was negative in $33(55 \%)$ and positive in 27 (45\%) cases. In a previous study CD44 was negative in $13.6 \%$ of the studied CRC cases and on reviewing the literature different percentages for CRC positive CD44 expression and this may be due different ways of its interpretation. In our study CD44 expression was significantly related to only both tumor size $(\mathrm{P}=0.006)$ and Dukes classification $(\mathrm{P}=0.019)$ and there was no relation between its expression and other used clinicopathological features. However a previous study showed a significant correlation between CD44 staining and CRC differentiation, as well as tumor stage and tumor site (35). It is obvious that there is controversy over the relationships between CD44 and CD133 expressions and the prognosis for colorectal cancer patients (31).

The expression of both CD133 and CD44 was positive in only 15 cases and both were negative in 25 cases. In a previous study CRC cells sorted for CD44+ displayed high tumorigenicity, especially in combination with CD133+ cells, whereas CD44- cells could not form new tumors (12). This goes with our results as we found that the positivity of both markers in the same cases was significantly related to metastasis $(\mathrm{P}=0.023)$.

The importance of the tumor microenvironment in promoting cancer initiation and tumor growth has been increasingly recognized over the past decade (36).The tumor microenvironment is characterized by chronic inflammation, which, instead of inhibiting tumor growth, favors tumor formation by stimulating cell proliferation, activating CSCs, and promoting metastasis (37). Leading the tumor inflammatory response are tumor associated macrophages (TAMs) (38).

Thirty seven cases $(61.7 \%)$ of our study group were negatively stained or showed infiltration with mild intensity of CD68 in TAMs and twenty three $(38.3 \%)$ cases showed moderate or strong infiltration intensity. The expression of CD68 was statistically significant in relation to the tumor size $(\mathrm{P}=0.018)$, the $\mathrm{T}(\mathrm{P}=0.007)$ and the $\mathrm{N}(\mathrm{P}=0.049)$ status of the tumor.

In a previous study a significant correlations were found between CD68 concentration in CRC and both the age of the patients and Dukes classification (39), however in another study low number of CD68-positive cells in CRC was significantly associated with several adverse clinical and histological tumor characteristics as the presence of metastases in local lymph nodes, distant metastases, advanced tumor stage, tumor cell invasion of blood, lymph vessels or perineural invasion and higher histological types (40). A correlation between high numbers of TAMs and rapid disease progression andpoor patient outcome has been observed for decades (41). So, TAMs-CSC cross talk was proposed. However a balance between pro- and anti-tumorigenic properties of TAMs may depend on their interaction with cancer cells, other stromal cells, and the tumor microenvironment (42) or be influenced by the degree of cell-cell contact (15). 
Among the cells of the immune system, the best represented in the peritumoral inflammatory infiltrate in CRC are macrophages and mast cells (43). In our study the expression of CD117 was negative or showed infiltration with mild intensity in 33 cases (55\%) and infiltration with moderate or strong intensity in 27 (45\%) of CRC cases.

Some studies have assessed a potential correlation between mast cell infiltration and colon cancer progression and poor prognosis (44- 45) while, other studies did not prove this role in CRC (46).

Our results showed that the expression of $\mathrm{CD} 117$ was significantly related to the $\mathrm{T}$ status of the tumor $(\mathrm{P}=0.011)$ and it was also significantly related to $\mathrm{M}$ status $(\mathrm{P}=0.003)$ and Dukes classification of the tumor $(\mathrm{P}=0.001)$.

The CRC cases with infiltration of moderate and strong intensity for both CD68 and CD117 had a strongly significant relation to only the $\mathrm{T}$ status $(\mathrm{P}=0.027)$, the metastasis $(\mathrm{M})(\mathrm{P}=0.034)$ and the presence of lymphovascular invasion $(\mathrm{P}=0.011)$.

Finally we assessed the relation between different markers used and we found that the expression of CD133 was significantly related to that of $\mathrm{CD} 44(\mathrm{P}=0.013)$ and to that of $\mathrm{CD} 117(\mathrm{P}=0.013)$ but was not related to the expression of CD68 ( $\mathrm{P}=0.92)$. CD44 expression was significantly related to $\mathrm{CD} 68$ expression $(\mathrm{P}=0.013)$ but not related to the expression of $\mathrm{CD} 117(\mathrm{P}=0.137)$. The significant relation we found between CSC markers and inflammatory markers may refer to a possible cross-talk between them which needs a confirmation.

Collectively, regarding the significant relation found between our studied markers and the presence of metastasis, we found this true for cases with dual expression of CD133 and CD44, cases with high concentration of CD117 and cases with high concentration of both CD68 and CD117.

To the best of our Knowledge no previous work studied the relation between the concentration of both TAMs and mast cells and clinicopathological features in patients with CRC or the relation between CSC and the inflammatory microenvironment in cases of CRC except very recently in review article that suggests a stem-like niche composed of numerous cell types, including macrophages, is important for promoting CSC self-renewal and maintenance, and likewise, CSC-derived factors induce pro-tumor signals in TAMs and that a complex cross talk occurs between these two cell types (23).

\section{Conclusion:-}

The significant relations between our studied markers and the clinicopathological features of CRC may refer to a role played by both CSCs (CD133 and CD44) and inflammatory microenvironment (TAMs and mast cells) in CRC progression, particularly distant metastasis, also the significant relation we found between different studied markers may also refer to a possible cross-talk between them which needs further studies for confirmation.

\section{References:-}

1. Wang K, Xu J, Zhang J and Huang J. Prognostic role of CD133 expression in colorectal cancer: a metaanalysis. BMC Cancer, 2012.12:573.

2. Ferlay J, Shin HR, Bray F, Forman D, Mathers C, Parkin DM. Estimates of worldwide burden of cancer in 2008: GLOBOCAN 2008. Int J Cancer 2010.127:2893-917.

3. Terzić J, Grivennikov S, Karin E, Karin M. Inflammation and colon cancer. Gastroentrology, 2010. 138: 21012114.

4. Tu Shi-Ming. Cancer: a "stem-cell” disease? Cancer Cell International, 2013.13:40.

5. Lin CY. Differentiation Therapy with Cancer Stem Cells. J Stem Cell Res Ther. 2014. 4: e117.

6. Todaro M, Francipane MG, Medema JP, Stassi G. Colon cancer stem cells: promise of targeted therapy. Gastroenterology. 2010;138(6):2151-2162.

7. Carpentino JE, Hynes MJ, Appelman HD, et al. Aldehyde dehydrogenase-expressing colon stem cells contribute to tumorigenesis in the transition from colitis to cancer. Cancer Res. 2009. 15;69(20):8208-8215.

8. Dalerba P, Dylla SJ, Park IK, et al. Phenotypic characterization of human colorectal cancer stem cells. Proc Natl Acad Sci U S A. 2007. 12;104(24):10158-10163.

9. Li L, Cole J, Margolin D.A. Cancer Stem Cell and Stromal Microenvironment. The Ochsner Journal. 2013. 13:109-118 
10. O'Brien CA, Pollett A, Gallinger S, Dick JE. A human colon cancer cell capable of initiating tumour growth in immunodeficient mice. Nature. 2007; 445(7123):106-110.

11. Horst D, Kriegl L, Engel J, Kirchner T, Jung A. Prognostic Significance of the Cancer Stem Cell Markers CD133, CD44, and CD166 in Colorectal Cancer 2009; Vol. 27, No. 8, 844-850.

12. Vaiopoulos AG, Kostakis ID, Koutsilieris M, Papavassiliou AG. Colorectal cancer stem cells. Stem Cells 2012; 30(3): 363-71.

13. Kaplan DH, Shankaran V, Dighe AS, Stockert E, Aguet M, Old LJ, Schreiber RD. Demonstration of an interferon gamma- dependent tumor surveillance system in immunocompetent mice. Proc. Natl. Acad. Sci. USA, 1998.95: 7556-7561.

14. Balkwill F, Mantovani A. Inflammation and cancer: back to Virchow? Lancet, 2001, 357(9255):539-545.

15. Forssell, J., Oberg, A., Henriksson, M.L., Stenling, R., Jung, A., Palmqvist, R. High macrophage infiltration along the tumor front correlates with improved survival in colon cancer. Clin. Cancer Res. 2007, 13, 14721479.

16. Jedinak, A., Dudhgaonkar, S., Sliva, D. Activated macrophages induce metastatic behavior of colon cancer cells. Immunobiology 2010, 215, 242-249.

17. Erreni M, Mantovani A, Allavena P. Tumor-associated macrophages (TAM) and inflammation in colorectal cancer. Cancer Microenvironment, 2011. 4: 141-154.

18. Gulubova M, Ananiev J, Yovchev Y, Julianov A, Karashmalakov A, Vlaykova T. The density of macrophages in colorectal cancer is inversely correlated to TGF-b1 expression and patients' survival. J. Mol. Hist.2013. 44: 679-692.

19. Shea-Donohue T, Stiltz J, Zhao A, Notari L, Mast cells, Curr Gastroenterol Rep, 2010, 12(5):349-357.

20. Galli SJ, Kalesnikoff J, Grimbaldeston MA, Piliponsky AM, Williams CM, Tsai M, Mast cells as "tunable" effector and immunoregulatory cells: recent advances, Annu Rev Immunol, 2005, 23:749-786.

21. Ribatti D, Crivellato E. Mast cells, angiogenesis and cancer, Adv Exp Med Biol, 2011, 716:270-288.

22. Huang EH, Wicha MS. Colon cancer stem cells: implications for prevention and therapy. Trends Mol Med 2008; 14: 503-509.

23. Sainz B. Jr., Carron E., Vallespinós M. and Machado H.L. Cancer Stem Cells and Macrophages: Implications in Tumor Biology and Therapeutic Strategies. 2016. Hindawi Publishing Corporation. Mediators of Inflammation. 2016, Article ID 9012369.

24. Kojima M, Ishii G, Atsumi N, Fujii S, Saito N, OchiaiA. Immunohistochemical detection of CD133 expression in colorectal cancer: a clinicopathological study. Cancer Sci. 2008, 99 (8): 1578-1583.

25. Carr NJ, Emory TS, Sobin LH. Epithelial neoplasms of the appendix and colorectum.An analysis of cell proliferation, apoptosis, and expression of p53, CD44, and bcl-2. Arch Pathol Lab Med. 2002; 126:837-41.

26. Hanada T, Nakagawa M, Emoto A, Nomura Y. Prognostic value of tumor-associated macrophage count in human bladder cancerInternational Journal of Urology.2000. 7(7):263-9.

27. Dabiri, S., Huntsman, D., Makretsov, N., Cheang, M., Gilks, B., Bajdik, C., Gelmon, K., Chia, S., and Hayes, $\mathrm{M}$. The presence of stromal mast cells identifies a subset of invasive breast cancers with a favorable prognosis. Mod.Pathol. 2004. 17, 690-695.

28. Cherciu I, Barbalan A., Pirici D., Margaritescu C., Saftoi A. Stem Cells, Colorectal Cancer and Cancer Stem Cell Markers Correlations. Current Health Sciences Journal. 2014. 40(3).

29. Ricci-Vitiani L., Lombardi D. G., Pilozzi E. et al. Identification and expansion of human colon-cancer-initiating cells, Nature. 2007; 445(7123): 111-115.

30. Choi D, Lee H, Hur K, Kim J, Park G, Jang S, Song S, Jang K, Paik S. Cancer stem cell markers CD133 and CD24 correlate with invasiveness and differentiation in colorectal adenocarcinoma. World J Gastroenterol. 2009. 14; 15(18): 2258-2264.

31. Hong I, Hong S, Chang Y, Lee W, Lee B, Kang Y, Kim Y, Paik I, Lee H. Expression of the Cancer Stem Cell Markers CD44 and CD133 in Colorectal Cancer: An Immunohistochemical Staining Analysis. Ann Coloproctol 2015; 31(3):84-91.

32. Ren F, Wei-Qi Sheng, Xiang Du. CD133: A cancer stem cells marker, is used in colorectal Cancers. World J Gastroenterol. 2013; 7; 19(17): 2603-2611.

33. Pitule P., Cedikova M, Daum O, Vojtisek J, Vycital O, Hosek P, Treska V, Hes O, Kralickova M, and LiskaV. Immunohistochemical Detection of Cancer Stem Cell Related Markers CD44 and CD133 in Metastatic Colorectal Cancer Patients. BioMed Research International. 2014, Article ID 432139.

34. Chen S, Song X, Chen Z, Li X, Li M, et al. CD133 Expression and the Prognosis of Colorectal Cancer: A Systematic Review and Meta-Analysis. PLoSONE. 2013; 8(2). 
35. Zavrides H.N., Zizi-Sermpetzoglou A, Panousopoulos D, Athanasas G, Elemenoglou I and Peros G. Prognostic evaluation of CD44 expression in correlation with bcl-2 and p53 in colorectal cancer. FOLIA HISTOCHEMICA ET CYTOBIOLOGICA. 2005; 43 (1): 31-36.

36. Fessler E., Dijkgraaf, De Sousa E Melo F., and Medema J. P., "Cancer stem cell dynamics in tumor progression and metastasis: is the microenvironment to blame?" Cancer Letters. 2013; 341(1): 97-104.

37. Plaks V., Kong N., Werb Z., and Plaks V., "The cancer stem cell niche: howessential is the niche in regulating stemness of tumor cells?" Cell Stem Cell, 2015. 16 (3): 225-238.

38. Noy R. and Pollard J.W. "Tumor-associatedmacrophages: from mechanisms to therapy," Immunity, 2014; 41(1): 49-61.

39. Hassan A. Immunohistochemical study of IL-17, perforin and CD68 in colorectal cancer .J. BioSci. Biotech. 2014, 3(3): 261-265.

40. Gulubova M, Ananiev J, Yovchev Y, Julianov A, Karashmalakov A, Vlaykova T. The density of macrophages in colorectal cancer is inversely correlated to TGF-b1 expression and patients' survival. J Mol Hist. 2013; 44: 679-692.

41. DeNardo D. G., Brennan D. J., Rexhepaj E. et al., "Leukocyte complexity predicts breast cancer survival and functionally regulates response to chemotherapy," Cancer Discovery, 2011; 1( 1): 54-67.

42. Jedinak, A.; Dudhgaonkar, S.; Sliva, D. Activated macrophages induce metastatic behavior of colon cancer cells. Immunobiology 2010. 215: 242-249.

43. Mogoanta S, Lungu C, Ilie C, Albu D, Totolici B, Neamtu C, Mitrut P, Dogaru C, Turculeanu A. Peritumoral inflammatory reaction in colon cancer. Histological and immunohistochemical study Rom J Morphol Embryol 2014, 55(4):1429-1435.

44. Malfettone A, Silvestris N, Saponaro C, Ranieri G, Russo A, Caruso S, Popescu O, Simone G, Paradiso A, Mangia A. High density of tryptase-positive mast cells in human colorectal cancer: a poor prognostic factor related to protease-activated receptor 2 expression. J. Cell. Mol. Med. 2013; 17(8): 1025-1037.

45. Wu X, Zou Y, He X,Yuan R, Chen Y, Lian L et al. Tumor-infiltrating mast cells in colorectal cancer as a poor prognostic factor. Int J Surg Pathol. 2013. 21(2) 111-20.

46. Xia Q, Wu X, Zhou Q, Jing-Zeng, Hou J, Pan Z and Zhang X. No relationship between the distribution ofmast cells and the survival of stage IIIB colon cancer patients Xia et al. Journal of Translational Medicine 2011, 9:88. 